удк 67.51

О. В. Карпова

Судебный участок № 23 Ленинского округа г. Иркутска, г. Иркутск, Российская Федерация

\title{
ОСНОВНЫЕ ПОДХОДЫ К ОБЩЕСОЦИАЛЬНОМУ ПРЕДУПРЕЖДЕНИЮ ПРЕСТУПНОГО ПОВЕДЕНИЯ ЖЕНЩИН
}

\begin{abstract}
АНнотАция. В системе мер предупреждения преступности особое место занимают меры общесоциального характера, которые направлены на улучшение социальных, экономических, правовых, условий жизни общества и, в целом, на повышение материального достатка населения, достижение стабильности в обществе, снижения социального расслоения среди граждан, повышение правосознания и правовой культуры граждан и др. Комплексный подход к реализации таких мер в отношении определенной категории лиц - женщин, совершивших преступления, особенно важен, поскольку, воздействуя на причины и условия их преступного поведения, возможно их исправление. Отмечается, что отдельное внимание следует акцентировать на правовом воспитании и повышении правовой культуры женщин, так как это имеет самое непосредственное значение для предупреждения женской преступности. При реализации данных мер необходимо учитывать, что они должны быть динамичными и учитывать современные достижения науки и технического прогресса.

кЛючЕВЫЕ слОВА. Общесоциальное предупреждение; женская преступность; система мер предупреждения.

ИНФОРМАЦИЯ О СТАТЬЕ. Дата поступления 1 октября 2016 г.; дата принятия к печати 25 октября 2016 г.; дата онлайн-размещения 30 ноября 2016 г.
\end{abstract}

O. V. Karpova

Court Circuit 23, Lenin District of Irkutsk, Irkutsk, Russian Federation

\section{MAIN APPROACHES TO GENERAL SOCIAL PREVENTION OF FEMALE CRIMINAL BEHAVIOR}

\begin{abstract}
In the system of prevention measures against criminality a special place is taken by the measures of general social character aimed at improving social, economic. legal conditions of public life and, on the whole, at raising public material wealth, achieving stability in the society, lowering social differentiation among citizens, increasing legal consciousness and legal culture of citizens, and so on. A complex approach to implementing such measures in regard of a certain category of persons - women having committed a crime - is particularly important because by affecting the causes and terms of their criminal behavior their reformation can be made possible. It is noted that a special attention must be focused on legal education and increasing women's legal culture because it has an immediate value for preventing female criminality. In implementing these measures, it is necessary to keep in mind that they must be dynamic and must consider the current achievements of science and technical progress. KEYWORDS. General social prevention; female criminality; system of prevention measures. ARTICLE INFO. Received October 1, 2016; accepted October 25, 2016; available online November 30, 2016.
\end{abstract}

Комплексный подход к реализации таких мер в отношении определенной категории лиц - женщин, совершивших преступления, особенно важен, поскольку, воздействуя на причины и условия их преступного поведения, возможно их исправление.

(C) O. B. Карпова, 2016

\section{Baikal Research Journal}


В системе мер предупреждения преступности особое место занимают меры общесоциального характера, которые направлены на улучшение социальных, экономических, правовых, условий жизни общества и, в целом, на повышение материального достатка населения, достижение стабильности в обществе, снижения социального расслоения среди граждан, повышение правосознания и правовой культуры граждан и др.

Главной целью криминологического исследования любого вида или формы преступного поведения является выработка комплекса мер по его предупреждению. В криминологической литературе в настоящее время отсутствует единообразный подход к содержательному наполнению терминов, которые отражают деятельность по выявлению, устранению, нейтрализации, ослаблению причин и условий, способствующих совершению преступлений.

Проанализировав различные подходы к содержанию таких терминов, следует сказать, что в настоящей статье в качестве основного термина принимается предупреждение преступности, которое можно определить как совокупность государственных и общественных мер, направленных на выявление, устранение, нейтрализацию причин и условий, детерминирующих преступность, в частности, преступность женщин. В свою очередь, деятельность по предупреждению преступлений представляет собой процесс взаимодействия субъектов и объектов предупреждения преступности, направленный на реализацию вышеуказанных мер. В этом процессе к субъектам относятся органы, должностные лица, а также граждане и организации, осуществляющие (прямо или косвенно) предупреждение преступности. К объектам предупредительного воздействия следует отнести противоречия в различных сферах общественной жизни, а применительно к настоящему исследованию - это противоречия в экономической, правовой, нравственной и семейно-бытовой сферах. В свою очередь само воздействие осуществляется посредством применения различных мер.

Анализ научной литературы показывает, что в настоящее время выделяется значительное количество различных мер, которые для их эффективного применения необходимо классифицировать по различным основаниям [1-4].

При классификации предупредительных мер по уровню воздействия принято различать общее (общесоциальное) и специально-криминологическое предупреждение преступлений. Особое место занимает индивидуальное предупреждение преступлений, представляющее собой конкретизацию общесоциальных и специально-криминологических мероприятий в отношении конкретного лица [5-8].

Общесоциальные мероприятия включают в себя комплекс мер, которые направлены на улучшение социальных, экономических, правовых, условий жизни общества и, в целом, на повышение материального достатка населения, достижение стабильности в обществе, снижения социального расслоения среди граждан, повышение правосознания и правовой культуры граждан и др. Реализация общесоциальных мероприятий, в свою очередь, решает как стратегические задачи (предупреждение преступности в целом), так и тактические задачи (предупреждение отдельных видов и форм преступности, например, преступности женщин). В этой связи, вышеуказанные мероприятия можно выделить как основополагающие и наиболее значимые, в том числе и для решения проблем предупреждения рецидивной преступности женщин.

Рассматривая общесоциальное предупреждение женской преступности (в том числе рецидивной), следует отметить, что данная деятельность включает в себя определение, выработку и реализацию системы общегосударственных мер в экономической, социальной, духовно-нравственной, правовой областях жизни общества в целях изменения положения женщин в сферах труда, быта, досуга и т. д.

\section{Baikal Research Journal}

электронный научный журнал Байкальского государственного университета 
Кризисные явления, периодически происходящие в экономике Российской Федерации $(1998,2008,2014-2015$ гг.), обостряют необходимость и подчеркивают значимость как государственной, так и общественной поддержки социально незащищенных слоев населения, к которым следует отнести женщин. Кризисные явления затрагивают прежде всего те отрасли, в которые доля занятых женщин значительно выше чем мужчин - торговля, сфера обслуживания, сфера питания и др. Массовое высвобождение женщин, снижение заработных плат, самым негативным образом сказываются на материальном и моральном их состоянии, создают повышенную эмоциональную напряженность, провоцируют на совершение необдуманных действий, в том числе, носящих противоправный характер. В этой связи трудоустройство, повышение квалификации профессиональная переподготовка женщин имеют весьма большое значение как мероприятия, направленные на предупреждение противоправного поведения женщин, повышение их социального уровня, востребованности на рынке труда.

Значимую роль в условиях кризиса должны играть службы занятости населения - организация ими таких мероприятий, как: «ярмарок-вакансий», психологической помощи лицам, оказавшимся в тяжелой жизненной ситуации, проведении дней бесплатной юридической помощи и др. Безусловно, к организации и проведению вышеуказанных мероприятий следует привлекать профессиональных психологов, юристов, потенциальных работодателей, т. е. комплексно подходить к решению такого рода проблем.

Также положительный эффект может дать поддержка (предоставление налоговых каникул, отнесение части государственных заказов и услуг и др.) на региональном и федеральном уровнях развития малого и среднего предпринимательства, что позволит создать для населения новые рабочие места, перераспределить высвободившееся рабочие ресурсы, предупредить безработицу и, как следствие, ее негативные криминальные и социально-психологические эффекты.

Думается, что творческий, нестандартный подход, в сочетании с планомерностью и последовательностью могут дать позитивный эффект в борьбе с безработицей, позволят снизить негативные последствия нынешнего социально-экономического кризиса в стране, получить хоть какой-нибудь источник дохода, прежде всего наименее защищенным слоям населения - женщинам, лицам с ограниченными возможностями, предотвратить совершение ими преступлений и правонарушений.

Как уже отмечалось выше работа по предупреждению женской преступности (в том числе рецидивной) должна носить комплексный характер и охватывать самые различные сферы жизнедеятельности, в том числе семью, где формируются их личностные черты.

Следует согласиться с мнением Ю. М. Антоняна, который считает, что семья, включая ребенка в свою эмоциональную матрицу, обеспечивает тем самым первичную, но чрезвычайно важную социализацию, т. е. «через себя» вводит его в структуру общества. Если этого не происходит, ребенок отчуждается от нее, вследствие чего закладывается основа для вероятного отдаления в будущем от норм общества, его институтов и ценностей, от малых социальных групп. Такое отдаление может принять форму стойкого дезадаптивного существования [9, с. 111].

Современная семья сталкивается с целым рядом проблем, которые порождены существующей экономической системой, несовершенством гражданского законодательства, бесправностью человека и бюрократизмом государственного аппарата. Эти проблемы естественно, структурируются по основным функциям семьи: экономическим, демографическим, социально-психологическим и социально-культурным ${ }^{1}$.

${ }^{1}$ См.: Концепция государственной программы улучшения положения женщин, семьи, охраны материнства и детства // Социально-экономические проблемы народонаселения. М. : РАН, 1992. С. 17-19.

\section{Baikal Research Journal}

электронный научный журнал Байкальского государственного университета 
Общеизвестно, что материальное благосостояние является той необходимой базой, на которой должны строиться отношения в семье. Если эта база отсутствует, то, как правило, должные отношения там обычно не складываются. Постоянная нужда в чем-либо формирует повышенную тревожность, зависть, толкает на совершение многих корыстных поступков. Без повышения уровня благосостояния народа не следует всерьез рассчитывать на снижение преступности вообще и женской в том числе [9, с. 219].

Безусловно, именно семья должна стать объектом серьезного профилактического воздействия со стороны государственных и общественных организаций. От эффективности такого воздействия напрямую зависит успех в вопросах предупреждения данного вида преступности. Отдельного внимания заслуживают малообеспеченные и остро нуждающиеся семьи, неблагополучные семьи и семьи, оказавшиеся в тяжелой жизненной ситуации.

Профилактика рецидивной преступности женщин требует также создания сети региональных центров, где им может быть оказана юридическая, психологическая и социальная помощь - то есть следует вести речь о психолого-педагогических и социально-юридических центрах помощи населению. Приоритетными задачами таких учреждений должны стать социальная защита и обслуживание граждан; помощь в реализации и защите прав семьи и детей; обеспечение психологической защиты граждан, недопущение их эмоциональных и психологических срывов; профилактика суицидального и девиантного поведения; пропаганда здорового образа жизни, отказа от вредных привычек и др.

Представляется, что реализация даже части вышеуказанных мероприятий, тем не менее, будет способствовать снижению уровня женской рецидивной преступности в исследуемом регионе.

Отдельное внимание следует акцентировать на правовом воспитании и повышении правовой культуры женщин, так как это имеет самое непосредственное значение для предупреждения женской преступности (в том числе рецидивной).

Проведенные в ходе настоящего исследования интервьюирования осужденных женщин четко показали, что многие их них не знали о степени и мере ответственности за совершаемые противоправные деяния; тем более, данные субъекты не могли разграничивать административную и уголовную ответственность (например, применительно к хищениям).

В этой связи правовое просвещение, разъяснение норм действующего законодательства, прежде всего, в части понимания, что такое есть правонарушение и преступление; виды ответственности и виды наказаний; правовые последствия привлечения уголовной ответственности и последствия судимости; ограничения и обязанности, налагаемые судом на осужденных женщин и др., думается, должно выступить серьезным профилактирующим инструментом, воздействовать положительным образом на лиц, находящихся на ранних стадиях криминализации личности.

Правовое просвещение должно носить комплексный межведомственный характер, в данной работе следует задействовать и активные слои общественности, наиболее сознательные слои населения. $K$ таковым, прежде всего, можно отнести студентов юридических вузов, членов молодежных организаций (например, «Молодая гвардия Единой России»), членов общественных организаций (например, «Ассоциация юристов России»), сама работа должна сочетать различные формы и методы - проведение всероссийский бесплатных дней юридической помощи, выездные мероприятии на предприятиях, городских и муниципальных образованиях, в исправительных учреждениях и др. Проводимые акции должны охватывать как можно более широкую возрастную группу - от школьников до лиц, находя-

\section{Baikal Research Journal}


щихся в преклонном возрасте, так как проведенное исследование показало, что возраст женщин-преступниц весьма разнообразен от 14 до 70 и более лет.

Привлечение к этой работе средств массовой информации (далее - СМИ), думается, не только повысит статус и значимость проводимых мероприятий, но и, безусловно, расширит охват целевой аудитории, причем, здесь также имеет смысл вести речь о комплексном подходе - о сочетании различных видов СМИ (телевидение, радио, интернет, печатные СМИ). Согласно исследованиям многих ученых, средства массовой информации занимают основное место по популярности среди населения по сравнению со всеми другими источниками правовой информации [10; 11$]$.

Конечной целью такой просветительской деятельности должно стать выработка у субъектов (как женщин, так и мужчин) четкого понимания, что такое есть преступление, какую ответственность несет человек, преступивший закон, а в глобальном масштабе - выработка законопослушного поведения и нетерпимого отношения к правонарушениям (в широком смысле этого слова).

Обобщая все вышесказанное относительно общесоциальных мероприятий можно отметить, что помимо комплексного подхода, сочетания различных форм и методов, постоянного поиска креативных решений, разнообразия субъектов профилактики, каждое мероприятие должно быть подкреплено достаточным материальными и информационными ресурсами. Кроме того, все проводимые мероприятия должны основываться на четкой, продуманной системе нормативно-правовых актов, в которой должны найти свое отражение как общемировые нормы и правила, так и учитываться региональная специфика и отличия субъектов Российской Федерации. Безусловно, общесоциальные профилактические мероприятия должны быть динамичными, учитывать современные достижения науки и технического прогресса и, ни в коей мере, не быть подвержены стагнации.

\section{Список использованной литературы}

1. Минстер М. В. Право женщин, осужденных к лишению свободы, на психологическую помощь: правовое обеспечение и практика реализации / М. В. Минстер // Криминологический журнал Байкальского государственного университета экономики и права. 2009. - № 3. - С. 46-51.

2. Лысова А. В. Социально-психологические характеристики женщин, совершивших преступления (по результатам исследования в женской исправительной колонии в Приморском крае) / А. В. Лысова, Л. И. Романова // Криминологический журнал Байкальского государственного университета экономики и права. - 2016. - Т. 10, № 2. - С. 252260. - DOI: 10.17150/1996-7756.2016.10(2).252-260.

3. Иониди Л. В. Криминологический аспект профилактики женской преступности / Л. В. Иониди, Л. В. Рябова // Вестник Северо-Кавказского гуманитарного института. 2016. - № 3. - С. 154-160.

4. Сарычева Н. В. Предупреждение женской преступности в ставропольском крае: проблемы и пути решения / Н. В. Сарычева // Вестник Северо-Кавказского гуманитарного института. - 2016. - № 3. - С. 241-245.

5. Сахаров А. Б. Теоретические основы предупреждения преступлений / А. Б. Сахаров // Советская юстиция. - 1972. - № 3. - С. 6.

6. Теоретические проблемы предупреждения правонарушений несовершеннолетних / Т. С. Барило, Э. Н. Дранищева, И. П. Лановенко [и др.] ; отв. ред. Ф. А. Лопушанский. Киев : Наукова думка, 1977. - 328 с.

7. Криминология : учебник / под ред. А. И. Долговой. - М. : Юристъ, 1997. - 512 с.

8. Антонян Ю. М. Преступность среди женщин / Ю. М. Антонян. - М. : Рос. право, 1992. $-256 \mathrm{c}$.

9. Синьков Д. В. Некоторые проблемы виктимологической профилактики женской преступности / Д. В. Синьков // Российский следователь. - 2009. - № 3. - С. 26-27.

\section{Baikal Research Journal}

электронный научный журнал Байкальского государственного университета 
10. Правовая пропаганда: В помощь идеологическому работнику / под ред. В. Н. Мицкевича. - М. : Юрид. лит., 1981. - 208 с.

11. Комаров А. А. К вопросу о феминизации преступности / А. А. Комаров // Юридические исследования. - 2016. — № 1. — C. 49-64. — DOI: 10.7256/2409-7136.2016.1.17189.

\section{References}

1. Minster M. V. The right of convicted women for psychological counseling: legal provision and implementation practice. Criminology Journal of Baikal National University of Economics and Law, 2009, no. 3, pp. 46-51. (In Russian).

2. Lysova A. V., Romanova L. I. Socio-psychological characteristics of female offenders (based on a study in a female correctional facility in Primorsky Territory). Criminology Journal of Baikal National University of Economics and Law, 2016, vol. 10, no. 2, pp. 252-260. DOI: 10.17150/1996-7756.2016.10(2).252-260. (In Russian).

3. Ionidea L. V., Ryabova L. V. Criminological aspects of preventing female criminality. Vestnik Severo-Kavkazskogo gumanitarnogo instituta = North-Caucasus Humanitarian Institute Bulletin, 2016, no. 3 (19), pp. 154-160. (In Russian).

4. Sarycheva N. V. Prevention of female crimes in Stavropol Territory: problems and solutions. Vestnik Severo-Kavkazskogo gumanitarnogo instituta = North-Caucasus Humanitarian Institute Bulletin, 2016, no. 3 (19), pp. 241-245. (In Russian).

5. Sakharov A. B. Theoretical basis of prevention of crimes. Sovetskaya yustitsiya = Soviet Justice, 1972, no. 3, p. 6. (In Russian).

6. Barilo T. S., Dranishcheva E. N., Lanovenko I. P. et al.; Lopushanskii F. A. (ed.). Teoreticheskie problemy preduprezhdeniya pravonarushenii nesovershennoletnikh [Theoretical problems of preventing juvenile delinquency ]. Kiev, Naukova dumka Publ., 1977. 328 p.

7. Dolgova A.I. (ed.). Kriminologiya [Criminology]. Moscow, Yurist» Publ., 1997. 512 p.

8. Antonyan Yu. M. Prestupnost' sredi zhenshchin [Criminality among women]. Moscow, Rossiiskoe pravo Publ., 1992. $256 \mathrm{p}$.

9. Sin'kov D. V. Some problems of victimological prevention of female criminality. Rossiiskii sledovatel' = Russian Investigator, 2009, no. 3, pp. 26-27. (In Russian).

10. Mitskevich V. N. (ed.). Pravovaya propaganda. V pomoshch' ideologicheskomu rabotni$k u$ [Legal propaganda. In aid of ideological worker]. Moscow, Yuridicheskaya Literature Publ., 1981. 208 p.

11. Komarov A. A. On issue of feminization of crime. Yuridicheskie issledovaniya = Legal Studies, 2016, no. 1, pp. 49-64. DOI: 10.7256/2409-7136.2016.1.17189. (In Russian).

\section{Информация об авторе}

Карпова Ольга Владилировна - мировой судья, судебный участок № 23 Ленинского округа г. Иркутска, 664053, г. Иркутск, ул. Розы Люксембург, 184/1, e-mail: dvsv@list.ru.

\section{Author}

Olga V. Karpova - Magistrate, Court Circuit 23, Lenin District of Irkutsk, 184/1 Rosa Luxemburg St., 664053, Irkutsk, Russian Federation; e-mail: dvsv@list.ru.

\section{Библиографическое описание статьи}

Карпова О. В. Основные подходы к общесоциальному предупреждению преступного поведения женщин / О. В. Карпова // Baikal Research Journal. - 2016. — T. 7, № 6. — DOI: 10.17150/2411-6262.2016.7(6).21.

\section{Reference to article}

Karpova O. V. Main approaches to general social prevention of female criminal behavior. Baikal Research Journal, 2016, vol. 7, no. 6. DOI: 10.17150/2411-6262.2016.7(6).21. (In Russian).

\section{Baikal Research Journal}

